Communication

\title{
Optimizing the Readout of Lanthanide-DOTA Complexes for the Detection of Ligand-Bound Copper(I)
}

\author{
Jill R. Hanna, Christopher Allan, Charlotte Lawrence, Odile Meyer, Neil D. Wilson \\ and Alison N. Hulme*
}

EaStCHEM School of Chemistry, The University of Edinburgh, Joseph Black Building, David Brewster Road, Edinburgh EH9 3FJ, UK; s0789206@ed-alumni.net (J.R.H.); C.Allan-3@sms.ed.ac.uk (C.A.);

s0569419@ed-alumni.net (C.L.); odile.meyer1@ac-strasbourg.fr (O.M.); s0094548@ed-alumni.net (N.D.W.)

* Correspondence: Alison.Hulme@ed.ac.uk; Tel.: +44-131-650-4711

Academic Editor: Margaret A. Brimble

Received: 22 March 2017; Accepted: 8 May 2017; Published: 14 May 2017

\begin{abstract}
The CuAAC 'click' reaction was used to couple alkyne-functionalized lanthanide-DOTA complexes to a range of fluorescent antennae. Screening of the antenna components was aided by comparison of the luminescent output of the resultant sensors using data normalized to account for reaction conversion as assessed by IR. A maximum 82 -fold enhanced signal:background luminescence output was achieved using a Eu(III)-DOTA complex coupled to a coumarin-azide, in a reaction which is specific to the presence of copper(I). This optimized complex provides a new lead design for lanthanide-DOTA complexes which can act as irreversible 'turn-on' catalytic sensors for the detection of ligand-bound copper(I).
\end{abstract}

Keywords: CuAAC click reaction; DOTA complexes; luminescence; $\mathrm{Cu}(\mathrm{I})$ sensor; picolinyl azides; coumarin azides

\section{Introduction}

The misregulation of copper in humans is linked with serious neurodegenerative disorders such as Menkes and Wilson's diseases [1-3], amyotrophic lateral sclerosis [4,5], and Alzheimer's disease [6,7]. To avoid the accumulation of excess copper, cells control copper pools rigorously through a range of uptake, storage, and trafficking mechanisms; this maintains a low concentration of labile copper ions, while simultaneously preserving sufficient cellular copper stores for function. It is thought that there are essentially no 'free' copper ions within the cell [8]. Although, there has been considerable progress in the development of fluorescent sensors for both copper(I) and copper(II) in recent years [9,10], most of these sensors rely on the detection of copper(I) through complexation of the 'free' metal ion giving rise to a concomitant change in spectroscopic properties of the sensor molecule in either a turn-on or turn-off sense. In an alternative strategy, we [11] and others [12] have reported reaction-based probes [13], which rely upon the irreversible formation or breaking of covalent bonds rather than the formation of supramolecular complexes. These 'reactive' probes can be used to detect the presence of ligand-bound copper(I); however, to date these sensors have been limited by either a modest signal output (10-fold increase in signal over background) [11], or the limit of detection $(20 \mu \mathrm{M})$ [12]. Clearly, the signal output which a turn-on catalytic sensor must generate in order to be 'useful' depends upon the specific application, but in the current study we set a goal of attaining a signal enhancement of $10^{2}-10^{3}$ fold.

Lanthanide chelates offer considerable advantages over the use of standard fluorescent dyes for detection in vivo, especially when there is significant autofluorescence [14]. Our sensor design 
(Figure 1) relies upon the copper(I)-catalyzed azide alkyne cycloaddition (CuAAC) coupling of two components-a lanthanide-DOTA complex 1 or $\mathbf{2}$, and a fluorescent azide antenna 3 - to give a luminescent complex 4 or 5 . Since we [11,15] and others [16-19] first introduced the use of bioorthogonal DOTA-alkyne complexed lanthanides such as $\mathbf{1}$ and $\mathbf{2}$ for 'click' chemistry they have found a range of applications; from metal ion reporting [11,20], to MR contrast agents [16,17,21-23]. It was envisaged that a dramatic improvement in their application to copper(I) sensing might be achieved through optimization of the energy transfer process. This might be achieved through: (i) screening of the fluorescent azides 3 used as the antenna; (ii) an investigation of the lanthanides at the core of the sensor itself $(\mathbf{1 a} \mathrm{Ln}=\mathrm{Eu}, \mathbf{1 b} \mathrm{Ln}=\mathrm{Tb}$ etc.); (iii) alteration of the linker length between the DOTA core and the fluorescent antenna (e.g., using DOTA-alkyne complexes 1a, 2a, etc.); and (iv) reversal of the component reactivity, i.e., DOTA-azide complexes reacting with fluorescent alkynes (not shown). Because the CuAAC reaction of DOTA complexes such as $\mathbf{2} \mathbf{a}$ and $\mathbf{2} \mathbf{b}$ has been reported to be sluggish $[18,19,24]$, rendering them unsuitable for use as sensors, we chose to focus this study on approaches (i) and (ii).

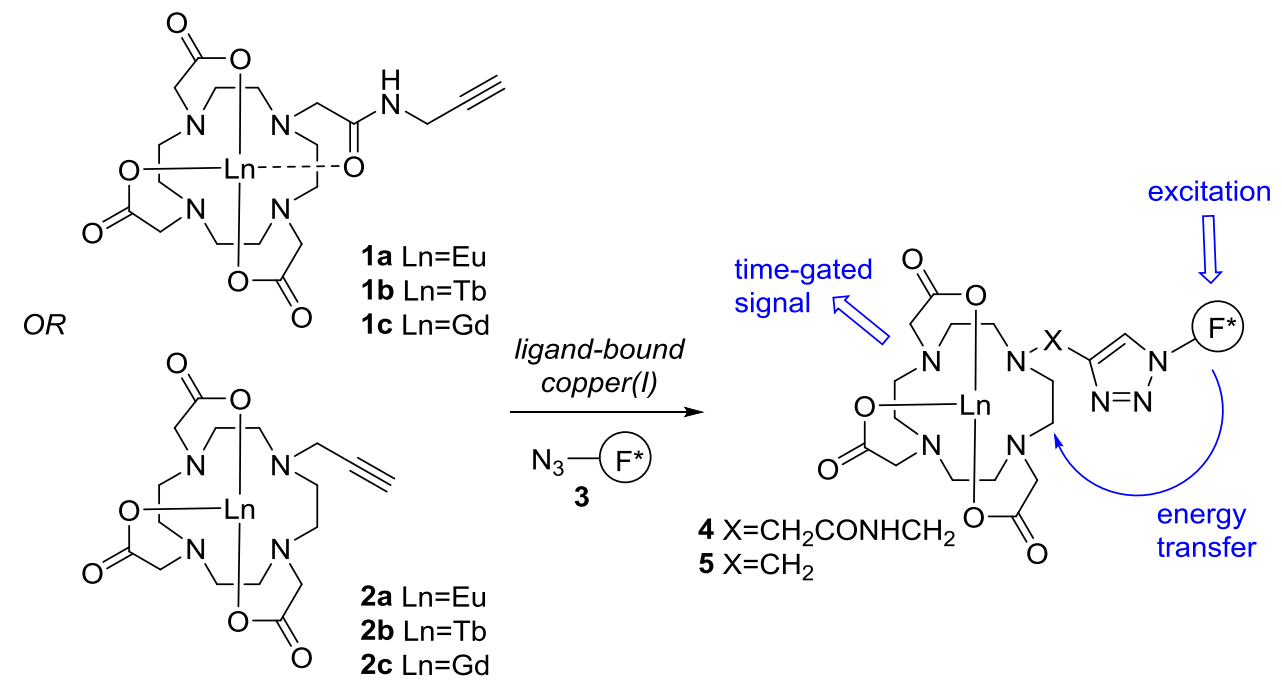

Figure 1. Sensor design for the detection of ligand-bound copper(I).

\section{Results and Discussion}

\subsection{Synthesis of Sensor Components}

Lanthanide DOTA complexes $\mathbf{1 a}$ and $\mathbf{1 b}$ were prepared by standard methods through functionalization of 1,4,7,10-tetraazacyclododecane-4,7,10-triacetic acid tri-tert-butyl ester $\left(\mathrm{DO}^{t} \mathrm{Bu}\right)$ [25] with propargyl chloroacetamide [26], followed by deprotection of the acid functionalities and complexation with either $\mathrm{Eu}(\mathrm{OTf})_{3}$ or $\mathrm{Tb}(\mathrm{OTf})_{3}$ (Supplementary Material (SM) Scheme S1) [11]. Although lanthanides have previously been shown to be sensitised by a variety of fluorophores [27-31], with a view to potential future biological applications of our sensor, we restricted ourselves to four classes of fluorophore azide (3) which have been shown to be cell-permeable and to have potential in two-photon excitation studies (Figure 2).

1. Picolinate-derivatized ligands have previously been shown to act as sensitizers for europium and terbium ions [32-35], to undergo cellular entry via diffusion, and to be suitable for two photon excitation studies. Thus picolinate azides $\mathbf{6}-\mathbf{9}$ were prepared from pyridine-2,6-dicarboxylic acid dimethyl ester through ready adaptation of the synthetic route to the 10-coordinate $N, N, N^{\prime}, N^{\prime}$-tetrakis[(6-carboxypyridin-2-yl)methyl]ethylenediamine (tpaen) ligand reported by Mazzanti et al. $[33,36,37]$ (SM Scheme S2; three steps (28\% overall), four steps (15\% overall), three steps ( $27 \%$ overall), and four steps ( $22 \%$ overall) respectively). 
2. Lanthanide complexes based on coumarin derivatives were pursued due to the known membrane permeability of coumarin azides [38], and previous reports of strong fluorescence activation of lanthanides by coumarin [39-42]. Coumarin azides 10 [43] and 11 [44] were both readily prepared in one step from commercially available starting materials (in $72 \%$ and $82 \%$ yields, respectively).

3. A derivative of carbostyril 124, azide 12, was chosen because lanthanides complexed with ligands functionalised with carbostyril 124 have been shown to have long-lifetimes, good water solubility, and measurable brightness [45-47]. Diazotization of carbostyril 124, followed by addition of sodium azide, yielded 12 (65\%) [48].

4. Finally, for comparison with our previously reported CuAAC reaction [11], dansyl azide $\mathbf{1 3}$ was prepared in two steps from dansyl chloride (70\% overall) [49].<smiles>[R]OC(=O)c1cccc(CN(CCCN)Cc2cccc(C(=O)O[R])n2)n1</smiles>

Figure 2. Fluorescent azides screened in this study.

\subsection{Component Coupling by the CuAAC Reaction}

In our original work we made use of glutathione ligands for the $\mathrm{CuAAC}$ reaction, as complexation of $\mathrm{Cu}(\mathrm{I})$ to the carboxylate anion of glutathione $\left(\mathrm{GS}^{-}\right)$, to give a $\mathrm{GS}^{-}-\mathrm{Cu}(\mathrm{I})$ complex, is thought to provide a pooling mechanism for $\mathrm{Cu}(\mathrm{I})$ in living cells [11,12]. However, this complex was found to be quite sensitive to environmental conditions and, in order to conduct a component screen, alternative catalyst systems were sought. The CuAAC reaction may be catalyzed by a range of ligand-bound copper(I) sources [50-52]. Notably, the readily accessible, stable ligand tris-(benzyltriazolemethyl)amine (TBTA) has been shown to bind strongly to the copper(I) ion [53], making it a good model for ligand-bound copper(I). Thus, to screen for alkyne/azide pairings with the most intense luminescent read-out, lanthanide-alkyne complex $\mathbf{1 a}$ or $\mathbf{1 b}$ was premixed with TBTA in ${ }^{t} \mathrm{BuOH}: \mathrm{H}_{2} \mathrm{O}$ (2:1), sodium ascorbate was added followed by copper(II) sulfate, finally the fluorescent azide ( 1 equivalent) was added and the mixture stirred at room temperature for $16 \mathrm{~h}$. To quench the reaction, the solution was gently shaken with a metal scavenger resin to remove the copper. Removal of both the scavenger resin and solvent gave crude products in which the formation of the luminescent DOTA complex could be confirmed by ESI-MS.

The optimum wavelength for excitation of each sensor complex was determined from the excitation spectrum of the fluorophore component (Table 1). Dilution experiments (performed on 19-Eu) indicated that a standard concentration of $100 \mu \mathrm{M}$ in water would give the sharpest luminescence emission spectra. The europium luminescence arising from ${ }^{5} \mathrm{D}_{\mathrm{o}}$ to ${ }^{7} \mathrm{~F}_{\mathrm{J}}$ transitions was evaluated at 593 or $615 \mathrm{~nm}$, depending on which offered the greatest increase in signal; whilst terbium luminescence was measured at $545 \mathrm{~nm}$ as this provides the most intense terbium transition. 
Table 1. Sensor Output after CuAAC Reaction ${ }^{\mathrm{a}}$.

\begin{tabular}{ccccccc}
\hline Entry & Alkyne & Azide & Sensor & $\lambda_{\mathbf{e x}} / \mathbf{n m}$ & Emission/cps $\mathbf{b}^{\text {(wavelength/nm) }}$ \\
\hline 1 & $\mathbf{1 a}$ & $\mathbf{6}$ & $\mathbf{1 4 - E u}$ & 325 & 100 & $(615)$ \\
2 & $\mathbf{1 b}$ & $\mathbf{6}$ & $\mathbf{1 4 - T \mathbf { b }}$ & 325 & 240 & $(545)$ \\
3 & $\mathbf{1 a}$ & $\mathbf{7}$ & $\mathbf{1 5 - E u}$ & 325 & 800 & $(615)$ \\
4 & $\mathbf{1 b}$ & $\mathbf{7}$ & $\mathbf{1 5 - T b}$ & 325 & 338 & $(545)$ \\
5 & $\mathbf{1 a}$ & $\mathbf{8}$ & $\mathbf{1 6 - E u}$ & 300 & 610 & $(615)$ \\
6 & $\mathbf{1 b}$ & $\mathbf{8}$ & $\mathbf{1 6 - T b}$ & 300 & 845 & $(545)^{\mathrm{c}}$ \\
7 & $\mathbf{1 a}$ & $\mathbf{9}$ & $\mathbf{1 7 - E u}$ & 300 & 1300 & $(545))^{\mathrm{c}}$ \\
8 & $\mathbf{1 b}$ & $\mathbf{9}$ & $\mathbf{1 7 - T b}$ & 300 & 791 & $(593)$ \\
9 & $\mathbf{1 a}$ & $\mathbf{1 0}$ & $\mathbf{1 8 - E u}$ & 345 & 5371 & $(545)$ \\
10 & $\mathbf{1 b}$ & $\mathbf{1 0}$ & $\mathbf{1 8 - T b}$ & 345 & 6078 & $(593)$ \\
11 & $\mathbf{1 a}$ & $\mathbf{1 1}$ & $\mathbf{1 9 - E u}$ & 325 & 56,592 & $(545)$ \\
12 & $\mathbf{1 b}$ & $\mathbf{1 1}$ & $\mathbf{1 9 - T b}$ & 325 & 10,000 & $(593)$ \\
13 & $\mathbf{1 a}$ & $\mathbf{1 2}$ & $\mathbf{2 0 - E u}$ & 345 & 16,665 & $(545)$ \\
14 & $\mathbf{1 b}$ & $\mathbf{1 2}$ & $\mathbf{2 0 - T b}$ & 345 & 25,000 & 4530 \\
15 & $\mathbf{1 b}$ & $\mathbf{1 3}$ & $\mathbf{2 1 - T b}$ & 350 & 4530 & \\
\hline
\end{tabular}

a Reagents and Conditions: $\mathrm{CuSO}_{4}(10 \mathrm{~mol} \%), \mathrm{NaAsc}(20 \mathrm{~mol} \%)$, TBTA $(10 \mathrm{~mol} \%),{ }^{t} \mathrm{BuOH}: \mathrm{H}_{2} \mathrm{O}(2: 1), \mathrm{rt}$, $16 \mathrm{~h}$; ${ }^{b}$ Relative emission at specified wavelength $\left(100 \mu \mathrm{M}\right.$ in $\mathrm{H}_{2} \mathrm{O}$, time delay $=0.076 \mathrm{~ms}$, slits $=10 \mathrm{~nm}$, sample window $=5 \mathrm{~ms}$, number of flashes $=20) ;{ }^{c}$ Decrease in signal from background.

\subsection{Initial Analysis of the Sensor Design by Component}

To facilitate comparison of the different sensors, the increase in lanthanide luminescence intensity between a background spectrum (1:1 mix of alkyne and azide components, $100 \mu \mathrm{M}$ in water) and the crude lanthanide sensor was expressed as a "fold increase" (Figure 3a,b, SM Tables S1-S4). These data indicate that-in terms of both the absolute signal brightness, and fold-increase over background-sensor 19-Eu, arising from the CuAAC coupling of DOTA-alkyne complex 1a with coumarin azide 11, offers the optimum readout. These experiments also highlighted that CuAAC coupling of picolinate-derived ligands to DOTA-alkyne complex 1a gave complexes (14-17)-Eu in which the europium was not efficiently sensitised. This is perhaps not surprising, because it has already been shown that, in general, sensitization of terbium by picolinate-derived ligands is more efficient [33]. However in the case of complexes 16-Tb and 17- $\mathbf{T b}$ (which combine terbium alkyne complex $\mathbf{1 b}$ with the di-picolinate ligands 8 and 9), surprisingly high background signals were observed for the 1:1 mix of the azide and alkyne components, accompanied by a significant decrease in signal (4-4.5-fold) on CuAAC coupling of the components. This suggests that the component azides $\mathbf{8}$ and $\mathbf{9}$ actually bind to, and sensitise, the terbium metal rather well; but that when they are separated from the terbium ion through CuAAC coupling to the DOTA core, this sensitization is significantly reduced. 


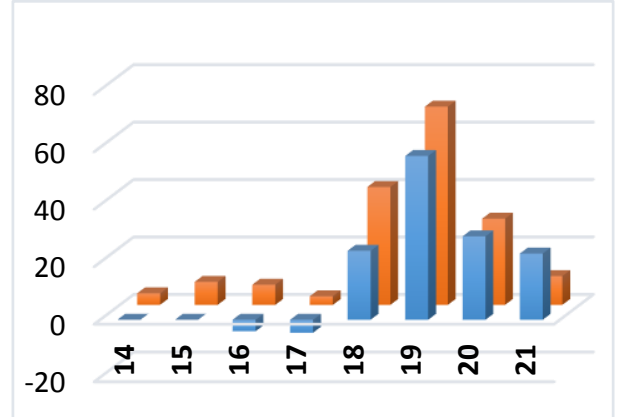

(a)

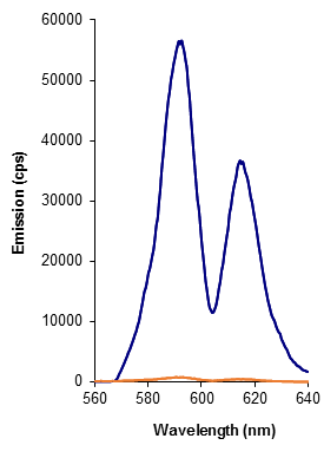

(b)

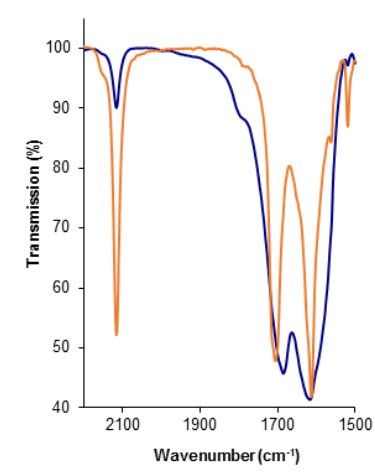

(c)

Figure 3. Change in Signal Output after CuAAC Reaction: (a) Sensor-Ln complex (Front (blue): Tb; Back (orange): Eu) vs. Signal increase over background (fold); (b) Luminescence of crude sensor 19-Eu (blue) and background 1a:11 (1:1) (orange), showing a 69-fold increase in emission (measured at $100 \mu \mathrm{M}$ in $\mathrm{H}_{2} \mathrm{O}$, time delay $=0.076 \mathrm{~ms}$, slits $=10 \mathrm{~nm}$, sample window $=5 \mathrm{~ms}$, number of flashes $\left.=20\right)$; (c) FT-IR analysis of azide peak at $2100 \mathrm{~cm}^{-1}$ for crude sensor 19-Eu (blue) with normalization of absorbance to carbonyl band at $1612 \mathrm{~cm}^{-1}$ in a 1:1 mixture of 1a:11 (orange).

\subsection{Normalization of Luminescence Output Data by IR}

In comparing the output data, it became clear that not all of the reactions had reached completion within the standard $16 \mathrm{~h}$ timeframe used for the CuAAC coupling reaction. This was evidenced by MS data which indicated the presence of both starting material(s) and coupled product (e.g., SM Figure S1 for 20-Tb), and is not surprising given the use of TBTA which is known to have relatively poor acceleration characteristics in the CUAAC reaction [50-52]. In seeking a rapid analysis method to determine the absolute increase in signal for each coupled product over the background signal, we were attracted to the use of vibrational spectroscopies such as IR to determine the extent to which the reaction had proceeded in the crude reaction mixture. In situ IR monitoring, using the azide absorption at $\sim 2100 \mathrm{~cm}^{-1}$ for quantification, has previously been used to reveal mechanistic insights into the $\mathrm{CuAAC}$ reaction [54]. The utility of this technique to determine click reaction conversions, based on IR absorption levels corresponding to residual azide, has also been reported in a variety of contexts [55-60]. IR monitoring is particularly appropriate in this instance, as both the sensor complex and the lanthanide-DOTA core are paramagnetic; rendering reaction monitoring and assessment of product purity by NMR challenging.

The presence of carbonyl bands in both the initial complex (1a or $\mathbf{1 b})$ and the CuAAC coupled product (4, Figure 1), which were not expected to shift in either position or intensity following the $\mathrm{CuAAC}$ reaction, led to an expectation that normalization and hence quantification of the conversion data could be achieved $[56,58]$. In order to demonstrate that there were no unexpected absorption peaks in the azide region of the coupled product, a sample of one of the complexes was purified by HPLC (SM Figure S2 for 19-Tb); the IR spectrum of the purified material showed the complete absence of signal at $2115 \mathrm{~cm}^{-1}$ which had previously been ascribed to the presence of unreacted azide in the crude material. In addition, experiments with the comparatively unreactive Eu-DOTA complex 2a showed that, under identical CuAAC conditions when there is no coupling reaction, the fluorophore azide absorptions remain at their original intensities. On this basis, IR spectra for the crude product mixtures from four of the most promising reactions were normalized (using the carbonyl bands indicated in Table 2) against composite spectra generated for the appropriate 1:1 mixtures of initial azide and alkyne components (Figure 3c, SM Tables S5 and S6). The percentage of unreacted azide remaining in the crude product mixtures was determined and was used to estimate the percentage conversion of each of these reactions. These conversion values were then used to adjust the maximal emission output of the lead sensors (Figure 4) to allow rapid determination of the 'optimum' sensor design; the maximal output for sensor 19-Eu was determined to be an 82-fold increase over background using 
this normalization process. This lead complex was purified by HPLC (SM Figure S3) and its UV-vis (SM Figure S4), MS (SM Figure S5) and ${ }^{1} \mathrm{H}-\mathrm{NMR}$ (SM) spectra were acquired.
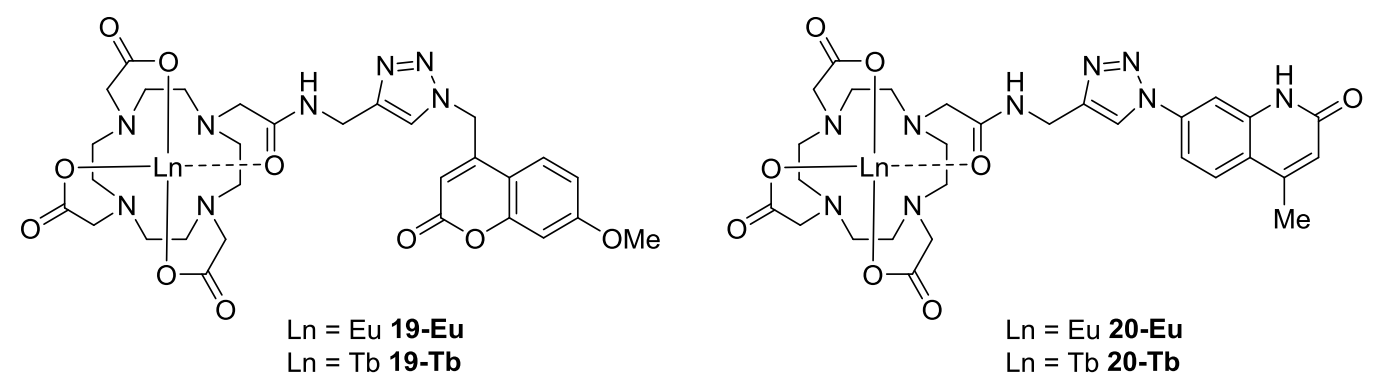

Figure 4. Structures of lead sensors 19-Eu/Tb and 20-Eu/Tb.

Table 2. Normalized Values for Signal Increase for Sensors 19 and 20.

\begin{tabular}{cccccc}
\hline Entry & Sensor & $\begin{array}{c}\text { Output }^{\mathbf{a}} \\
\text { (fold) }\end{array}$ & $\begin{array}{c}\text { Wavenumber } \\
\mathbf{( c m}^{-\mathbf{1}} \mathbf{)}\end{array}$ & $\begin{array}{c}\text { Conversion } \\
(\mathbf{\%})\end{array}$ & $\begin{array}{c}\text { Normalized Output } \\
\text { c } \\
\text { (fold) }\end{array}$ \\
\hline 1 & $\mathbf{1 9 - E u}$ & 69 & $1612(1612)$ & 84 & 82 \\
2 & $\mathbf{1 9 - T b}$ & 57 & $1614(1615)$ & 85 & 67 \\
3 & $\mathbf{2 0 - E u}$ & 30 & $1628(1624)$ & 83 & 36 \\
4 & $\mathbf{2 0 - T b}$ & 29 & $1614(1626)$ & 68 & 43 \\
\hline
\end{tabular}

a Signal increase over background; ${ }^{b}$ Carbonyl bands used to normalize data for \% conversion calculation: 1:1 component mixture (product spectra); ${ }^{\mathrm{C}}$ Sensor output normalized to $100 \%$ conversion for CuAAC reaction.

\subsection{Metal Ion Specificity for Formation of the Optimum Complex 19-Eu}

Metal ion specificity for the optimum sensor was confirmed through coupling of DOTA alkyne 1a and coumarin azide 11 to give 19-Eu in three solutions, one containing $\mathrm{Na}(\mathrm{I}), \mathrm{K}(\mathrm{I}), \mathrm{Fe}(\mathrm{II}), \mathrm{Ni}(\mathrm{II}), \mathrm{Zn}(\mathrm{II})$, and $\mathrm{Cu}(\mathrm{II})$ (10 mol\% each); a second containing $\mathrm{CuSO}_{4}(10 \mathrm{~mol} \%)$, sodium ascorbate $(20 \mathrm{~mol} \%)$ and TBTA $(10 \mathrm{~mol} \%)$; and a third in which there were no metal ions present. Each solution was stirred for $16 \mathrm{~h}$ at room temperature and, following metal ion extraction as described in Section 2.2, was excited at $325 \mathrm{~nm}$. The lanthanide luminescence was measured at $593 \mathrm{~nm}$; the mixed ion solution (without $\mathrm{Cu}(\mathrm{I})$ ) showed no increase in signal over background (at $\sim 800 \mathrm{cps}$ ), whilst the reaction conducted in the presence of $\mathrm{Cu}(\mathrm{I})$ showed the expected increase in signal output to $\sim 60,000 \mathrm{cps}$. These experiments confirmed that this CuAAC coupling reaction has the potential to selectively detect ligand-bound copper(I) in the presence of other biologically relevant metal ions.

\section{Materials and Methods}

\subsection{General Procedure for the Synthesis of CuAAC Coupled Complexes 14-21}

To Eu-DOTA complex 1a, or Tb-DOTA complex $\mathbf{1 b}$ (1 eq; dissolved at $20 \mathrm{mM}$ concentration) in ${ }^{\mathrm{t}} \mathrm{BuOH}: \mathrm{H}_{2} \mathrm{O}(2: 1)$ was added TBTA (0.1 eq) and the mixture was allowed to stir for $15 \mathrm{~min}$. Sodium ascorbate ( 0.2 eq; $0.1 \mathrm{M}$ aq.) was added and the mixture was allowed to stir for $15 \mathrm{~min}$ followed by the addition of copper(II) sulfate (0.1 eq; $0.1 \mathrm{M}$ aq.). After a further $15 \mathrm{~min}$ of stirring, the appropriate azide was added (1 eq) and the solution was allowed to stir under nitrogen at room temperature for $16 \mathrm{~h}$. QuadraPure-IDA ${ }^{\circledR}$ metal scavenger resin was added and the mixture was gently shaken at room temperature overnight, during which the blue colour of the solution faded. The resin was removed by filtration and the solvent was then removed in vacuo to give the crude triazole sensor. 


\subsection{Luminescence Measurements on Crude CuAAC Coupled Complexes 14-21}

Excitation and emission fluorescence spectra were measured using a Horiba Jobin Yvon Fluoromax-P instrument. Lanthanide emission spectra were measured using a time-delayed setting on the same instrument.

Solutions of the crude mixtures of (14-21)-Eu/ Tb were prepared $\left(100 \mu \mathrm{M}, \mathrm{H}_{2} \mathrm{O}\right)$. The lanthanide luminescence intensity of each solution was measured at the stated $\lambda_{\max }$ of the antenna component (Table 1) using the following settings: time delay $=0.076 \mathrm{~ms}$, slits $=10 \mathrm{~nm}$, sample window $=5 \mathrm{~ms}$, number of flashes $=20$. The output was recorded as the relative emission (cps) at the wavelength $(\mathrm{nm})$ corresponding to the most intense lanthanide transition (Table 1). A fold-response was calculated by comparing this emission (in cps) to that of a solution of the sensor components $(100 \mu \mathrm{M}$ each, 1:1 mixture in $\mathrm{H}_{2} \mathrm{O}$ ) stirred at $\mathrm{rt}$ for $16 \mathrm{~h}$, measured under identical conditions at the same wavelength.

\subsection{Normalization of Output of CuAAC Coupled Complexes 19 and 20 by IR}

IR were measured on a Perkin Elmer Paragon 100 FT-IR machine, and ASCII files of the resultant spectra used for subsequent data handling in Excel.

Samples were prepared as $\mathrm{KBr}$ die (at a final concentration of $0.5 \mathrm{mg}$ azide, alkyne or crude complex in $120 \mathrm{mg} \mathrm{KBr}$ ). The reproducibility of sample preparation was confirmed by preparing triplicate dies of pure sensor 19-Tb. A spectrum of the 1:1 alkyne:azide starting component mixtures was generated from the reference spectra of the two starting materials using the principle of additivity of the two absorbers present. Normalization of absorbance between reference and crude product spectra was carried out at the wavenumber shown, allowing for a slight shift $\left(<10 \mathrm{~cm}^{-1}\right)$ in the $C=O$ stretch between the two spectra (Table 2). Normalized luminescence output data (expressed as a fold increase) were calculated by estimating the \% remaining azide in the normalized IR spectrum of the crude product mixture (Beer Lambert Law) and using this to determine the \% reaction conversion by which the measured output could be proportionately adjusted.

\subsection{Data for Purified Lead Complex 19-Eu}

UV-vis $(\mathrm{nm}) \lambda_{\max }=219,325 ;{ }^{1} \mathrm{H}-\mathrm{NMR} \delta\left(600 \mathrm{MHz}, \mathrm{D}_{2} \mathrm{O}\right) 32.76(1 \mathrm{H}, \mathrm{s}), 31.26(1 \mathrm{H}, \mathrm{s}), 30.60(1 \mathrm{H}, \mathrm{s}), 30.46$ $(1 \mathrm{H}, \mathrm{s}), 7.67(1 \mathrm{H}, \mathrm{s}), 6.92-6.63(3 \mathrm{H}, \mathrm{m}), 5.08(2 \mathrm{H}, \mathrm{s}), 4.85(2 \mathrm{H}, \mathrm{s}), 3.82(3 \mathrm{H}, \mathrm{s}), 0.06(1 \mathrm{H}, \mathrm{s}),-0.37(1 \mathrm{H}, \mathrm{s})$, $-2.57(1 \mathrm{H}, \mathrm{s}),-2.67(1 \mathrm{H}, \mathrm{s}),-3.33(1 \mathrm{H}, \mathrm{s}),-4.55(1 \mathrm{H}, \mathrm{s}),-5.85(1 \mathrm{H}, \mathrm{s}),-7.18(1 \mathrm{H}, \mathrm{s}),-7.64(1 \mathrm{H}, \mathrm{s})$, $-7.95(1 \mathrm{H}, \mathrm{s}),-11.04(1 \mathrm{H}, \mathrm{s}),-11.33(1 \mathrm{H}, \mathrm{s}),-11.66(1 \mathrm{H}, \mathrm{s}),-12.22(1 \mathrm{H}, \mathrm{s}),-14.23(1 \mathrm{H}, \mathrm{s}),-14.40$ $(1 \mathrm{H}, \mathrm{s}),-14.85(1 \mathrm{H}, \mathrm{s}),-15.67(2 \mathrm{H}, \mathrm{s}),-16.86(1 \mathrm{H}, \mathrm{s}) ; \mathrm{m} / z\left(\mathrm{ESI}+, \mathrm{H}_{2} \mathrm{O}\right) 823\left(\left[{ }^{153} \mathrm{EuM}+\mathrm{H}\right]^{+}, 74\right), 821$ $\left(\left[{ }^{151} \mathrm{EuM}+\mathrm{H}\right]^{+}, 44\right), 412\left(\left[{ }^{153} \mathrm{EuM}+2 \mathrm{H}\right]^{2+}, 100\right), 411\left(\left[{ }^{151} \mathrm{EuM}+2 \mathrm{H}\right]^{2+}, 80\right)$.

\section{Conclusions}

The detection of copper(I) species in a native biological setting (i.e., not one in which copper has been artificially introduced at non-physiological conditions) has the potential to enhance our understanding of a range of diseases, including those in which copper metabolism is misregulated (such as Menkes and Wilson's diseases) and those in which copper is thought to be either causative or related to disease progression (such as Alzheimer's disease). However, this detection is reliant on the design of sensors which are capable of reacting with predominantly ligand-bound copper, with a signal output which is not perturbed by the intrinsic properties of the biological milieu (e.g., inherent cellular fluorescence). For these reasons, sensors which are constructed using the exquisitely metal-ion selective CuAAC reaction [61] and which produce luminescent read-outs are particularly promising. By screening a range of potential antenna, using classes of fluorophore which are known to be cell-permeable, we have identified a sensor pairing which gives nearly two orders of magnitude signal increase over background, overcoming previous limitations in sensor design. Pairing this knowledge with recent advancements in ligand acceleration of the CuAAC reaction [62] could enable the very rapid detection of ligand-bound copper in an intracellular environment. 
Supplementary Materials: The following are available online: Schemes S1 and S2 and synthetic details for preparation of DOTA complexes 1a and 1b, and azides 6-13 [63,64]; spectroscopic data for complexes 14-21; Tables S1-S4: luminescence spectra for complexes 14-21; Figure S1: ESI mass spectrum for crude reaction product 20-Tb; Figure S2: HPLC chromatogram of crude reaction product 19-Tb; Tables S5 and S6: normalized IR spectra for complexes 18 and $19 ;{ }^{1} \mathrm{H}$ and ${ }^{13} \mathrm{C}$-NMR spectra for azides 7, 8 and 9; HPLC chromatogram, UV-vis, MS and ${ }^{1} \mathrm{H}-\mathrm{NMR}$ spectra for purified complex 19-Eu.

Acknowledgments: We thank Patricia Richardson and Kenneth G. McKendrick for helpful discussions. We thank the EC FP6 (Marie Curie EST Fellowship to JRH; Contract: MEST-CT-2005-020744) and EPSRC (Grant Ref. $\mathrm{EP} / \mathrm{C} 539001)$ for funding.

Author Contributions: A.N.H. and J.R.H. conceived and designed the experiments; J.R.H., C.A., C.L., O.M. and N.D.W. performed the experiments; A.N.H. and J.R.H. analyzed the data; A.N.H. wrote the paper.

Conflicts of Interest: The authors declare no conflict of interest.

\section{References}

1. Ala, A.; Walker, A.P.; Ashkan, K.; Dooley, J.S.; Schilsky, M.L. Wilson's disease. Lancet 2007, 369, $397-408$. [CrossRef]

2. Bandmann, O.; Weiss, K.H.; Kaler, S.G. Wilson's disease and other neurological copper disorders. Lancet Neurol. 2015, 14, 103-113. [CrossRef]

3. Crisponi, G.; Nurchi, V.M.; Fanni, D.; Gerosa, C.; Nemolatob, S.; Faa, G. Copper-related diseases: From chemistry to molecular pathology. Coord. Chem. Rev. 2010, 254, 876-889. [CrossRef]

4. Valentine, J.S.; Hart, P.J. Misfolded CuZnSOD and amyotrophic lateral sclerosis. Proc. Natl. Acad. Sci. USA 2003, 100, 3617-3622. [CrossRef] [PubMed]

5. Tokuda, E.; Furukawa, Y. Copper homeostasis as a therapeutic target in amyotrophic lateral sclerosis with SOD1 mutations. Int. J. Mol. Sci. 2016, 17, 636. [CrossRef] [PubMed]

6. Barnham, K.J.; Masters, C.L.; Bush, A.I. Neurodegenerative diseases and oxidative stress. Nat. Rev. Drug Discov. 2004, 3, 205-214. [CrossRef] [PubMed]

7. Greenough, M.A.; Ramírez Munoz, A.; Bush, A.I.; Opazo, C.M. Metallo-pathways to Alzheimer's disease: Lessons from genetic disorders of copper trafficking. Metallomics 2016, 8, 831-839. [CrossRef] [PubMed]

8. Rae, T.D.; Schmidt, P.J.; Pufahl, R.A.; Culotta, V.C.; O’Halloran, T.V. Undetectable intracellular free copper: The requirement of a copper chaperone for superoxide dismutase. Science 1999, 284, 805-808. [CrossRef] [PubMed]

9. Ramos-Torres, K.M.; Chang, C.J. Synthetic fluorescent probes for studying copper in biological systems. Chem. Soc. Rev. 2015, 44, 4400-4414.

10. Aron, A.T.; Ramos-Torres, K.M.; Cotruvo, J.A., Jr.; Chang, C.J. Recognition- and reactivity-based fluorescent probes for studying transition metal signaling in living systems. Acc. Chem. Res. 2015, 48, 2434-2442. [CrossRef] [PubMed]

11. Viguier, R.F.H.; Hulme, A.N. A sensitized europium complex generated by micromolar concentrations of copper(I): Toward the detection of copper(I) in biology. J. Am. Chem. Soc. 2006, 128, 11370-11371. [CrossRef] [PubMed]

12. Taki, M.; Iyoshi, S.; Ojida, A.; Hamachi, I.; Yamamoto, Y. Development of highly sensitive fluorescent probes for detection of intracellular copper(I) in living systems. J. Am. Chem. Soc. 2010, 132, 5938-5939. [CrossRef] [PubMed]

13. Jun, M.E.; Roy, B.; Ahn, K.H. “Turn-on" fluorescent sensing with "reactive” probes. Chem. Soc. Rev. 2011, 47, 7583-7601. [CrossRef] [PubMed]

14. Butler, S.J.; Lamarque, L.; Pala, R.; Parker, D. EuroTracker dyes: Highly emissive europium complexes as alternative organelle stains for live cell imaging. Chem. Sci. 2014, 5, 1750-1756. [CrossRef]

15. Germeroth, A.I.; Hanna, J.R.; Karim, R.; Kundel, F.; Lowther, J.; Neate, P.G.N.; Blackburn, E.A.; Wear, M.A.; Campopiano, D.J.; Hulme, A.N. Triazole biotin: A tight-binding biotinidase-resistant conjugate. Org. Biomol. Chem. 2013, 11, 7700-7704. [CrossRef] [PubMed]

16. Prasuhn, D.E., Jr.; Yeh, R.M.; Obenaus, A.; Manchester, M.; Finn, M.G. Viral MRI contrast agents: Coordination of $\mathrm{Gd}$ by native virions and attachment of $\mathrm{Gd}$ complexes by azide-alkyne cycloaddition. Chem. Commun. 2007, 1269-1271. [CrossRef] [PubMed] 
17. Song, Y.; Kohlmeir, E.K.; Meade, T.J. Synthesis of multimeric MR contrast agents for cellular imaging. J. Am. Chem. Soc. 2008, 130, 6662-6663. [CrossRef] [PubMed]

18. Jauregui, M.; Perry, W.S.; Allain, C.; Vidler, L.R.; Willis, M.C.; Kenwright, A.M.; Snaith, J.S.; Stasiuk, G.J.; Lowe, M.P.; Faulkner, S. Changing the local coordination environment in mono- and bi- nuclear lanthanide complexes through 'click' chemistry. Dalton Trans. 2009, 6283-6285. [CrossRef] [PubMed]

19. Stasiuk, G.J.; Lowe, M.P. Click chemistry with lanthanide complexes: A word of caution. Dalton Trans. 2009, 9725-9727. [CrossRef] [PubMed]

20. Junker, A.K.R.; Tropiano, M.; Faulkner, S.; Sørensen, T.J. Kinetically inert lanthanide complexes as reporter groups for binding of potassium by 18-crown-6. Inorg. Chem. 2016, 55, 12299-12308. [CrossRef] [PubMed]

21. Verwilst, P.; Eliseeva, S.V.; Carron, S.; Vander Elst, L.; Burtea, C.; Dehaen, G.; Laurent, S.; Binnemans, K.; Muller, R.N.; Parac-Vogt, T.N.; et al. A modular approach towards the synthesis of target-specific MRI contrast agents. Eur. J. Inorg. Chem. 2011, 3577-3585. [CrossRef]

22. Mastarone, D.J.; Harrison, V.S.R.; Eckermann, A.L.; Parigi, G.; Luchinat, C.; Meade, T.J. A Modular System for the synthesis of multiplexed magnetic resonance probes. J. Am. Chem. Soc. 2011, 133, 5329-5337. [CrossRef] [PubMed]

23. Desbois, N.; Pacquelet, S.; Dubois, A.; Michelin, C.; Gros, C.P. Easy access to heterobimetallic complexes for medical imaging applications via microwave-enhanced cycloaddition. Beilstein J. Org. Chem. 2015, 11, 2202-2208. [CrossRef] [PubMed]

24. Molloy, J.K.; Kotova, O.; Peacock, R.D.; Gunnlaugsson, T. Synthesis of luminescent homo-dinuclear cationic lanthanide cyclen complexes bearing amide pendant arms through the use of copper catalysed (1,3-Huisgen, CuAAC) click chemistry. Org. Biomol. Chem. 2012, 10, 314-322. [CrossRef] [PubMed]

25. Axelsson, O.; Olsson, A. Synthesis of Cyclen Derivatives. Patent WO2006112723 A1, 26 October 2006.

26. Martinelli, J.; Balali-Mood, B.; Panizzo, R.; Lythgoe, M.F.; White, A.J.P.; Ferretti, P.; Steinke, J.H.G.; Vilar, R. Coordination chemistry of amide-functionalised tetraazamacrocycles: Structural, relaxometric and cytotoxicity studies. Dalton Trans. 2010, 39, 10056-10067. [CrossRef] [PubMed]

27. Dos Santos, C.M.G.; Harte, A.J.; Quinn, S.J.; Gunnlaugsson, T. Recent developments in the field of supramolecular lanthanide luminescent sensors and self-assemblies. Coord. Chem. Rev. 2008, 252, 2512-2527. [CrossRef]

28. Moore, E.G.; Samuel, A.P.S.; Raymond, K.N. From antenna to assay: Lessons learned in lanthanide luminescence. Acc. Chem. Res. 2009, 42, 542-552. [CrossRef] [PubMed]

29. Montgomery, C.P.; Murray, B.S.; New, E.J.; Pal, R.; Parker, D. Cell-penetrating metal complex optical probes: Targeted and responsive systems based on lanthanide luminescence. Acc. Chem. Res. 2009, 42, 925-937. [CrossRef] [PubMed]

30. Heffern, M.C.; Matosziuk, L.M.; Meade, T.J. Lanthanide probes for bioresponsive imaging. Chem. Rev. 2014, 114, 4496-4539. [CrossRef] [PubMed]

31. Wang, X.; Chang, H.; Xie, J.; Zhao, B.; Liu, B.; Xu, S.; Pei, W.; Ren, N.; Huang, L.; Huang, W. Recent developments in lanthanide-based luminescent probes. Coord. Chem. Rev. 2014, 273-274, 201-212. [CrossRef]

32. Sendor, D.; Hilder, M.; Juestel, T.; Junk, P.C.; Kynast, U.H. One dimensional energy transfer in lanthanoid picolinates. Correlation of structure and spectroscopy. New J. Chem. 2003, 27, 1070-1077. [CrossRef]

33. Chatterton, N.; Bretonnière, Y.; Pécaut, J.; Mazzanti, M. An efficient design for the rigid assembly of four bidentate chromophores in water-stable highly luminescent lanthanide complexes. Angew. Chem. Int. Ed. 2005, 44, 7595-7598. [CrossRef] [PubMed]

34. Pope, S.J.A.; Laye, R.H. Design, synthesis and photophysical studies of an emissive, europium based, sensor for zinc. Dalton Trans. 2006, 3108. [CrossRef] [PubMed]

35. Liu, J.; Morikawa, M.; Kimizuka, N. Conversion of molecular information by luminescent nanointerface self-assembled from amphiphilic Tb(III) complexes. J. Am. Chem. Soc. 2011, 133, 17370-17374. [CrossRef] [PubMed]

36. Behera, H.; Ramkumar, V.; Madhavan, N. Cation-transporting peptides: Scaffolds for functionalized pores? Chem. Eur. J. 2015, 21, 10179-10184. [CrossRef] [PubMed]

37. Gracia, S.; Arrachart, G.; Marie, C.; Chapron, S.; Miguirditchian, M.; Pellet-Rostaing, S. Separation of Am(III) by solvent extraction using water-soluble $\mathrm{H}_{4}$ tpaen derivatives. Tetrahedron 2015, 71, 5321-5336. [CrossRef]

38. Beatty, K.E.; Xie, F.; Wang, Q.; Tirrell, D.A. Selective dye-labeling of newly synthesized proteins in bacterial cells. J. Am. Chem. Soc. 2005, 127, 14150-14151. [CrossRef] [PubMed] 
39. Rodríguez-Ubis, J.C.; Alonso, M.T.; Brunet, E. Synthesis and luminiscence properties of europium(III) and terbium(III) complexes of aminopolycarboxylic acid ligands containing 3-aroylcoumarin. Tetrahedron Lett. 1994, 35, 8461-8464. [CrossRef]

40. Féau, C.; Klein, E.; Kerth, P.; Lebeau, L. Synthesis of a coumarin-based europium complex for bioanalyte labelling. Bioorg. Med. Chem. Lett. 2007, 17, 1499-1503. [CrossRef] [PubMed]

41. Borbas, K.E.; Bruce, J.I. Synthesis of asymmetrically substituted cyclen-based ligands for the controlled sensitisation of lanthanides. Org. Biomol. Chem. 2007, 5, 2274-2282. [CrossRef] [PubMed]

42. Féau, C.; Klein, E.; Kerth, P.; Lebeau, L. Synthesis and properties of europium complexes derived from coumarin-derivatized azamacrocycles. Synth. Met. 2009, 159, 528-536. [CrossRef]

43. van Kalkeren, H.A.; Bruins, J.J.; Rutjes, F.P.J.T.; van Delft, F.L. Organophosphorus-catalysed Staudinger reduction. Adv. Synth. Catal. 2012, 354, 1417-1421. [CrossRef]

44. Jawalekar, A.M.; Meeuwenoord, N.; Cremers, J.G.O.; Overkleeft, H.S.; van der Marel, G.A.; Rutjes, F.P.J.T.; van Delft, F.L. Conjugation of nucleosides and oligonucleotides by [3+2] cycloaddition. J. Org. Chem. 2008, 73, 287-290. [CrossRef] [PubMed]

45. Tremblay, M.; Halim, M.; Sames, D. Cocktails of $\mathrm{Tb}^{3+}$ and $\mathrm{Eu}^{3+}$ complexes: A general platform for the design of ratiometric optical probes. J. Am. Chem. Soc. 2007, 129, 7570-7577. [CrossRef] [PubMed]

46. Ge, P.; Selvin, P.R. Carbostyril derivatives as antenna molecules for luminescent lanthanide chelates. Bioconjugate Chem. 2004, 15, 1088-1094. [CrossRef] [PubMed]

47. Sammes, P.G.; Yahioglu, G. Modern bioassays using metal chelates as luminescent probes. Nat. Prod. Rep. 1996, 13, 1-28. [CrossRef] [PubMed]

48. Kamaruddin, M.A.; Hossain, M.I.; Jarasrassamee, B.; Cheng, H.-C.; Ung, P.; O’Malley, W.; Thompson, P.; Graham, B.; Scanlon, D. A facile, click chemistry-based approach to assembling fluorescent chemosensors for protein tyrosine kinases. Bioorg. Med. Chem. Lett. 2011, 21, 329-331. [CrossRef] [PubMed]

49. Maruani, A.; Alom, S.; Canavelli, P.; Lee, M.T.W.; Morgan, R.E.; Chudasama, V.; Caddick, S. A mild TCEP-based para-azidobenzyl cleavage strategy to transform reversible cysteine thiol labelling reagents into irreversible conjugates. Chem. Commun. 2015, 51, 5279-5282. [CrossRef] [PubMed]

50. Li, L.; Zhang, Z. Development and applications of the copper-catalyzed azide-alkyne cycloaddition (CuAAC) as a bioorthogonal reaction. Molecules 2016, 21, 1393. [CrossRef] [PubMed]

51. Haldón, E.; Nicasio, M.C.; Pérez, P.J. Copper-catalysed azide-alkyne cycloadditions (CuAAC): An update. Org. Biomol. Chem. 2015, 13, 9528-9550. [CrossRef] [PubMed]

52. Berg, R.; Straub, B.F. Advancements in the mechanistic understanding of the copper-catalyzed azide-alkyne cycloaddition. Beilstein J. Org. Chem. 2013, 9, 2715-2750. [CrossRef] [PubMed]

53. Chan, T.R.; Hilgraf, R.; Sharpless, K.B.; Fokin, V.V. Polytriazoles as copper(I)-stabilizing ligands in catalysis. Org. Lett. 2004, 6, 2853-2855. [CrossRef] [PubMed]

54. Sum, S.; Wu, P. Mechanistic insights into $\mathrm{Cu}(\mathrm{I})$-catalyzed azide-alkyne 'click' cycloaddition monitored by real time infrared spectroscopy. J. Phys. Chem. A 2010, 114, 8331-8336.

55. Lau, Y.H.; Wu, Y.; de Andrade, P.; Galloway, W.R.J.D.; Spring, D.R. A two-component 'double-click' approach to peptide stapling. Nat. Protoc. 2015, 10, 585-594. [CrossRef] [PubMed]

56. Albuszis, M.; Roth, P.J.; Pauer, W.; Moritz, H.-U. Macroporous uniform azide- and alkyne-functional polymer microspheres with tuneable surface area: synthesis, in-depth characterization and click-modification. Polym. Chem. 2014, 5, 5689-5699. [CrossRef]

57. Michinobu, T.; Hiraki, K.; Inazawa, Y.; Katayama, Y.; Masai, E.; Nakamura, M.; Ohara, S.; Shigehara, K. Click synthesis and adhesive properties of novel biomass-based polymers from lignin-derived stable metabolic intermediate. Polymer J. 2011, 43, 648-653. [CrossRef]

58. Gokmen, M.T.; Camp, W.V.; Colver, P.J.; Bon, S.A.F.; Prez, F.E. Fabrication of porous “clickable" polymer beads and rods through generation of high internal phase emulsion (HIPE) droplets in a simple microfluidic device. Macromolecules 2009, 42, 9289-9292. [CrossRef]

59. Misaka, H.; Kakuchi, R.; Zhang, C.; Sakai, R.; Satoh, T.; Kakuchi, T. Synthesis of well-defined macrocyclic poly( $\delta$-valerolactone) by "click cyclization". Macromolecules 2009, 42, 5091-5096. [CrossRef]

60. Hasegawa, T.; Umeda, M.; Numata, M.; Li, C.; Bae, A.H.; Fujisawa, T.; Haraguchi, S.; Sakurai, K.; Shinkai, S. "Click chemistry" on polysaccharides: a convenient, general, and monitorable approach to develop $(1 \rightarrow 3)$ - $\beta$-D-glucans with various functional appendages. Carbohydr. Res. 2006, 341, 35-40. [CrossRef] [PubMed] 
61. Lau, Y.H.; Rutledge, P.J.; Watkinson, M.; Todd, M.H. Chemical sensors that incorporate click-derived triazoles. Chem. Soc. Rev. 2011, 40, 2848-2866. [CrossRef] [PubMed]

62. Uttamapinant, C.; Tangpeerachaikul, A.; Grecian, S.; Clarke, S.; Singh, U.; Slade, P.; Gee, K.R.; Ting, A.T. Fast, cell-compatible click chemistry with copper-chelating azides for biomolecular labeling. Angew. Chem. Int. Ed. 2012, 51, 5852-5856. [CrossRef] [PubMed]

63. Zeng, X.; Coquiere, D.; Alenda, A.; Garrier, E.; Prange, T.; Li, Y.; Reinaud, O.; Jabin, I. Efficient synthesis of calix[6]tmpa: A new calix[6]azacryptand with unique conformational and host-guest properties. Chem. Eur. J. 2006, 12, 6393-6402. [CrossRef] [PubMed]

64. Mohamed, G.G.; El-Gamel, N.E. Structural, spectroscopic and thermal characterization of 2-tert-butylaminomethylpyridine-6-carboxylic acid methylester and its $\mathrm{Fe}(\mathrm{III}), \mathrm{Co}(\mathrm{II}), \mathrm{Ni}(\mathrm{II}), \mathrm{Cu}(\mathrm{II})$, Zn(II) and UO(2)(II) complexes. Spectrochim. Acta A Mol. Biomol. Spectrosc. 2005, 61, 1089-1096. [CrossRef] [PubMed]

Sample Availability: Not Available.

(C) 2017 by the authors. Licensee MDPI, Basel, Switzerland. This article is an open access article distributed under the terms and conditions of the Creative Commons Attribution (CC BY) license (http://creativecommons.org/licenses/by/4.0/). 